\title{
Cel1, Probably Encoding a Cellobiohydrolase Lacking the Substrate Binding Domain, Is Expressed in the Initial Infection Phase of Claviceps purpurea on Secale cereale
}

\author{
Ulrike Müller, Klaus B. Tenberge, Birgitt Oeser, and Paul Tudzynski \\ Institut für Botanik, Westfälische Wilhelms-Universität, Schloßgarten 3, D-48149 Münster, Germany \\ Received 21 August 1996. Accepted 12 November 1996.
}

\begin{abstract}
At the host-pathogen interface of hyphae penetrating host cell walls in the rye ovary, a lack of cellulase-gold labeling of $\beta$-1,4-glucan in host cell walls indicates that enzymatic degradation of cellulose might be an important factor during the infection of rye by Claviceps purpurea. Using cbhI from Trichoderma reesei as a probe, a putative cellulase gene (cell) was isolated from a genomic library of the $C$. purpurea strain T5. The coding region of 1,616 bp contains two introns and a putative signal peptidase cleavage site, leaving a coding capacity of $\mathbf{4 3 7}$ amino acids for the mature protein. The derived amino acid sequence shares significant homology with other fungal cellobiohydrolases and lacks the substrate binding domain. Expression analysis using reverse transcriptase-polymerase chain reaction (RT-PCR) shows that cell is induced during the first days of infection of rye by $C$. purpurea. It may be involved in the penetration and degradation of host cell walls by depolymerizing plant $\beta$-1,4-glucan and, therefore, play a role in the infection process.
\end{abstract}

Additional keywords: enzyme-gold localization, fungal cellulase, gene expression, host-pathogen interaction, molecular cloning.

The ubiquitous ascomycete Claviceps purpurea (Fr.) Tul. causes ergot in cereals and grasses. It is strictly organ specific, exclusively attacking young ovaries and replacing the plant ovarian tissue with the ergot sclerotia. The infection process of Claviceps, e.g. on rye, is characterized by a biotrophic, balanced interaction, restricting the damage of the host plant to the ovarian tissue, and ensuring a continuous flow of plant carbohydrates to the developing fungal mycelium (for a detailed review see Tudzynski et al. 1995).

Because of this biotrophic mode of infection, C. purpurea secretes only limited amounts of cell wall degrading enzymes in axenic culture. Nevertheless, such enzymes could be of importance during the first stages of infection and also in the

Corresponding author: P. Tudzynski

E-mail: tudzyns@uni-muenster.de

Accession number of the CEL1 gene: Y07550. process of establishing and maintaining an open contact to the host's vascular tissue. To elucidate the role of extracellular cell wall degrading enzymes during the parasitic cycle of $C$. purpurea, we designed a molecular approach involving cloning and characterization of corresponding genes, expression studies (e.g., via RT-PCR) and secretion studies (via immunogold TEM) in planta. We have purified and characterized an extracellular endo- $\beta$-1,3-glucanase (Brockmann et al. 1992), which has been shown by immunogold labeling to be secreted in planta (Tenberge and Tudzynski 1995; K. B. Tenberge, B. Brockmann and P. Tudzynski, unpublished). This fungal $\beta$ 1,3-glucanase might be involved in the degradation of the host's phloem callose or of wound callose produced by defence reactions. Two xylanases have been purified and characterized, and two xylanase genes ( $x y l 1$ and $x y l 2)$ have been recently cloned and sequenced (S. Giesbert and P. Tudzynski, unpublished). Two putative endo-polygalacturonase genes, closely linked and arranged head-to-tail, have been cloned, sequenced, and shown to be expressed in planta by RT-PCR (Tenberge et al. 1996).

Immunogold labeling has demonstrated that these endopolygalacturonases and other pectinases most likely cause structural modification and degradation of plant pectin (Tenberge et al. 1996). Therefore, they are probably utilized for the intercellular growth during the colonization of the ovary and for the degradation of the entire plant cell walls during the replacement of the ovary with the fungal sphacelium. However, the activity of fungal pectinases might not be sufficient for this purpose. In addition, the ergot fungus directly penetrates plant cell walls and forms intracellular hyphae during the primary penetration of the epidermis, during the colonization of the mesophyll and later for the tapping of xylem vessels (Tudzynski et al. 1995). Since grasses have developed a special cell wall type containing small amounts of pectins and considerably large amounts of xylans in addition to the major polysaccharide portion of cellulose (Carpita and Gibeaut 1993), xylanases and cellulases as well as pectinases are expected to be necessary for breaking down the major cell wall components during infection.

In this article, we present cytological evidence that cellulolytic enzymes are involved in the infection process and we describe the cloning and characterization of a putative cellulase gene and its expression during the infection process. 


\section{RESULTS}

\section{In situ localization of $\beta$-1,4-glucan in healthy and} colonized pistil tissues.

To localize cellulose in situ with the enzyme-gold technique, a cellulase preparation from Trichoderma was linked to a gold sol and characterized for its specificity. The protein envelope of the gold particles contained three endo- $\beta-1,4-$ glucanases and was apparently free from xylanases as determined by biochemical analyses with hydrophobic interaction chromatography, sodium dodecyl sulfate-polyacrylamide gel electrophoresis (SDS-PAGE), native isoelectric focusing, and activity staining. Carboxymethylcellulose (CMC)-agarose plate assays showed that the prepared cellulase-gold sol had CMC-degrading activity. In all labeling experiments, a preincubation of the gold sol with CMC led to a reduction of the labeling density below the background level (data not shown).

Treatment of healthy plant tissue with the cellulase-gold sol resulted in a specific gold labeling of all carpel cell walls but not of homogeneous plant cuticles or lignified cell wall layers. Distinct gold labeling was also present in very thin, young growing cell walls, which already exhibited a fibrillar ultrastructure, but in this case the labeling density was lower (data not shown).

At the interface of host mesophyll cells and hyphae growing intercellularly in the plant middle lamella, the plant cell walls exhibited ultrastructural alterations but were still present around the invading hyphae. Host cell walls which were in direct contact with the pathogen surface showed a significantly reduced cellulase-gold labeling compared to the considerably higher labeling density of walls distant from the host-pathogen interface or in non-colonized tissue areas (Fig. 1A, B). The reduced or absent labeling with the cellulase-gold sol indicated a decrease or lack of homo- $\beta-1,4$-glucan in the remaining polysaccharide network of the altered host wall in the near vicinity of the pathogen.

Fungal hyphae, which actively penetrate the cell walls of living mesophyll cells of the host ovary, actually grow intracellularly and the fungal surface comes to a direct contact with the host plasma membrane. Hyphae first invaginate the host wall and the host plasma membrane. The host wall surrounding the invading hyphae is present at the penetration point and gets thinner along the hyphal branch leading inside the host cell. At distant areas from the penetration point, the host cell wall is completely absent between the fungal cell wall and the host plasma membrane. At the host-pathogen interface between the wall surface of the intracellular hyphae and the host plasma membrane, no cellulase-gold label was visible, while a distinct gold label was present over the wall of the same host cell away from the zone of invagination (Fig. 1C). The extensive colonization of the ovary late in the first infection phase, structurally disorganized the host cells and resulted in large zones of necrotic tissue. In this stage, host cell wall remnants which were in direct contact to fungal cells exhibited ultrastructural alterations and a significant decrease of cellulase-gold labeling (Fig. 1D). No gold particles were seen over the fungal cell walls of hyphae in external mycelia (not shown) or hyphae distant from the host-pathogen interface, whereas sometimes few cellulase-gold particles were present in the fungal walls which were in direct contact with host walls of a reduced labeling density (Fig. 1A, D). In the subsequent sphacelial infection stage, the ovary cells and their cell walls are completely replaced with fungal structures.

These observations indicate an enzymatic cellulose degradation. Therefore, we decided to analyze the cellulolytic system of $C$. purpurea using molecular genetics, although very little cellulolytic activity can be detected in the liquid axenic culture of this fungus (U. Müller, unpublished).

\section{Cloning and characterization of a putative cellulase gene.}

The low level of secreted cellulases in axenic cultures of $C$. purpurea makes difficult the cloning of cellulase genes via isolation of proteins. Therefore, we searched for a heterologous probe and tested several cloned fungal cellulase genes for homology with genomic DNA of $C$. purpurea. Whereas the endoglucanase genes egI (Penttilä et al. 1986) and egII (Saloheimo et al. 1988) from Trichoderma reesei did not give rise to signals in Southern blotting experiments (even under nonstringent conditions), the cellobiohydrolase genes $c b h I$ (Shoemaker et al. 1983) and cbhII (Teeri et al. 1987) of the same organism showed some homology. A 0.7-kb fragment of cbhI containing the catalytic domain yielded the best signals and was used for the screening of a genomic Lambda library of strain T5 (see Materials and Methods section). We screened 50,000 plaques and selected four Lambda clones showing strong homology to the probe. A 2.1-kb HincII fragment present in all positive clones was subcloned and sequenced; it showed $70 \%$ homology to the $c b h I$ sequence, containing the downstream part of the gene (Fig. 2).

To obtain a complete copy of the gene, a 5.6-kb PstI fragment was subcloned in pUC 19 and characterized in detail (Fig. 2). Sequence analysis showed the presence of an open reading frame of 1,616 bp interrupted by two introns (Fig. 3), as indicated by the presence of intron consensus sequences (Ballance 1991). The position of the downstream intron was confirmed by sequencing an RT-PCR fragment defined by primers UM4 and UM6 (see below). The presence of a signal peptidase cleavage site indicates the presence of a signal peptide of 19 amino acids, leading to a mature protein of 437 amino acids. Comparison of the derived amino acid sequence (Fig. 4) with other cellulases yielded significant homology to several fungal cellobiohydrolases; the strongest homology is found for the $C B H-1$ gene of Humicola grisea (63.7\%) (Azevedo et al. 1990) and the CFAM2 gene of Fusarium oxysporum (65.3\%) (Sheppard et al. 1994). Interestingly, the open reading frame of cell is shorter than in most other fungal $\mathrm{CBH}$ genes, as it contains only the catalytic domain. The corresponding stop codon was found in all four Lambda clones, and there is no significant homology beyond this stop codon to the other fungal cellulase genes. Therefore, the protein encoded by cell obviously lacks the substrate binding domain. Comparably short versions of cellobiohydrolase have been detected in Phanerochaete chrysosporium, Cochliobolus carbonum, and Cryphonectria parasitica (Covert et al. 1992; Sposato et al. 1995; Wang and Nuss 1995).

Because in other species of fungi a set of homologous cellulase genes exists, e.g., $P$. chrysosporium (Covert et al. 1992), genomic DNA of strain T5 was probed with cell DNA to determine its copy number. Under moderate (Fig. 5) and even under low stringency (data not shown) only one copy of the gene could be detected, indicating that other cellulase genes are absent or have no significant homology to cell. 


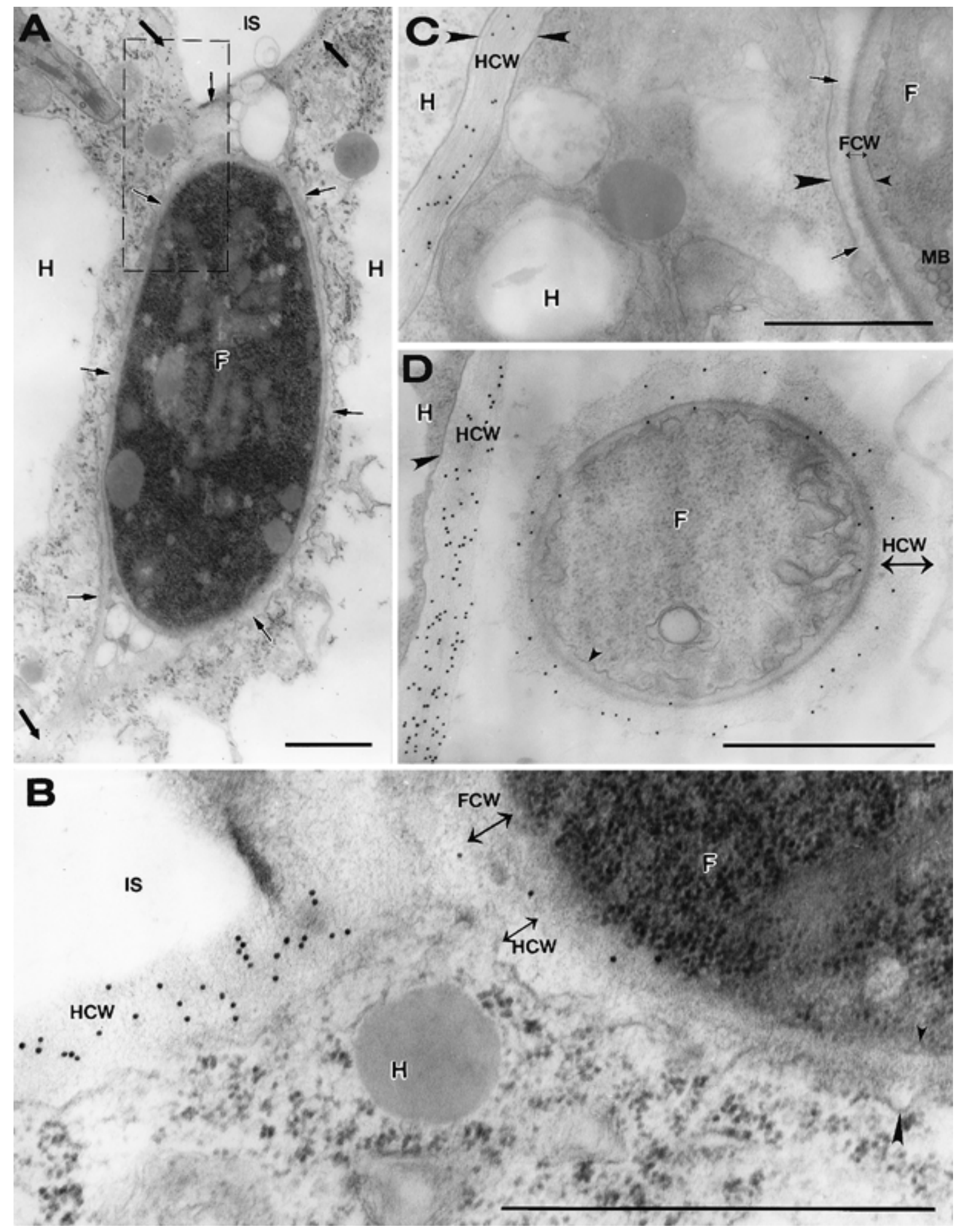

Fig. 1. Enzyme-gold localization of $\beta$-1,4-glucan with a cellulase-gold sol in rye ovaries infected with Claviceps purpurea during the infection stage I (see Fig. 6A). A, Hypha growing intercellularly between host cells in the carpel mesophyll, 4 days postinoculation (dpi); B, enlargement of the area indicated in $\mathbf{A} ; \mathbf{C}$, intracellular hypha after penetration of a living host cell in the chalazal region of the carpel mesophyll, 6 dpi; $\mathbf{D}$, fungal hypha in the affected mesophyll tissue of the ovary cap, 6 dpi. F, fungal hypha; FCW, fungal cell wall; $\mathrm{H}$, host cell; HCW, host cell wall; IS, intercellular space; MB, multivesicular body; small arrowhead, fungal plasma membrane; large arrowhead, host plasma membrane; thin arrows indicate reduced or absent cellulase-gold labeling, thick arrows indicate non-altered labeling. Scale bars $=1 \mu \mathrm{m}$. 
Analysis of the upstream noncoding sequence of cell (Fig. 3 ) showed the presence of typical fungal promoter elements such as a TATA-Box at position -166, several CAATsequences and a CT-rich region as well as several putative binding sites for regulatory proteins (see Discussion section), indicating that cell represents an active gene.

\section{Expression of cell.}

Since cellulolytic activity of $C$. purpurea mycelia in axenic culture strains the limits of detection, we tested the expression of cell in vitro with Northern analysis. However, the signals obtained (if any) were very weak, indicating that the expression level of cell is very low in axenic culture or the transcript is not readily detectable by Northern hybridization. Because only very limited amounts of RNA can be extracted from infected rye ovaries, we used RT-PCR instead of the Northern technique for expression studies in planta. Primers were designed (UM4 and UM6, Figs. 2 and 3) that spanned an introncontaining region of the gene. They allow differentiation between RNA-derived PCR products and PCR products arising from DNA contamination which are larger due to the intron. RNA preparations from axenically grown mycelia give rise to PCR products of the expected size (386 bp), grown on CMC or crystalline cellulose substrates, confirming that cell is transcribed under these conditions (Fig. 6A). To allow the analysis of the expression of cell during the parasitic cycle of $C$. purpurea, rye florets were inoculated with conidia, and infected ovaries were collected after various time intervals $(5,10,15$, and 20 days, termed stages I to IV, see Fig. 7). RNA was prepared from this material and used for RT-PCR. Only RNA from stage I, up to 5 days postinoculation, gave rise to a cell PCR product of the expected size, whereas primers specific for the glyceraldehyde-phosphate-dehydrogenase (GPD) gene from C. purpurea (Jungehülsing et al. 1994), used as a control, yielded PCR fragments up to stage IV (Fig. 6B). The identity of the cell RT-PCR product was confirmed by sequence analysis: altogether six independent clones obtained from this PCR fragment contained the sequence of cell confined by primers UM4 and 6, lacking exactly the proposed intron sequence (see Fig. 2). Recently, we could show that the same RT-PCR approach (using the same RNA preparations) yielded fragments with polygalacturonase primers up to stage III (Tenberge et al. 1996) and with primers for two xylanase genes in all stages ( $\mathrm{S}$. Giesbert and P. Tudzynski, unpublished). This indicates that the detection of cell mRNA only in stage I probably is not due to differences in the quality of
RNA. In any case this shows that cell is expressed in parasitic culture namely in the first days of infection.

\section{DISCUSSION}

Cytological evidence for the involvement of cellulases in the colonization of host tissue by $C$. purpurea.

The interaction between $C$. purpurea and rye has been studied with light- and electron microscopy and contradictory results have been published with regard to the mode of fungal growth along the infection route in cereal ovaries (Campbell 1958; Shaw and Mantle 1980). Therefore, we decided to undertake a detailed cytological analysis of the course of infection, focusing on cell-wall modifications in the interaction process in order to discover molecular mechanisms responsible for fungal growth (K. B. Tenberge, unpublished; Tudzynski et al. 1995). First hints of the potential involvement of fungal cellulases during the infection course arose from ultrastructural analysis, which demonstrated that the early infection of rye ovaries by $C$. purpurea is not only intercellular but also intracellular (Tenberge and Tudzynski 1994). The fungus penetrated host walls which contain cellulose according to the model of molecular architecture of grass cell walls generalized by Carpita and Gibeaut (1993). Assuming that this model is also valid for walls of grass ovaries and developing fruits, cellulolytic activity could be involved in breaching the cellulose microfibrils in the polysaccharide network and in the complete depolymerization of the host walls in later infection stages.

Using the enzyme-gold method, a gold sol linked to a cellulase preparation from Trichoderma proved to be useful in identifying host cell walls within ultrathin sections of infected tissue. Far more important, the specificity of the gold sol allowed the localization of homo- $\beta-1,4$-glucan in situ and indicated the presence of cellulose. The cellulase-gold sol would possibly also bind to xyloglucan if this hemicellulose contains homo- $\beta$-1,4-glucan regions of sufficient length. In grass cell walls, however, glucuronoarabinoxylans and not xyloglucan are the principal components of hemicellulose (Carpita and Gibeaut 1993). Due to the CMC-degrading capacity of the gold-particle envelope, the gold sol labeled the substrates of a putative fungal endo- $\beta$-1,4-glucanase. As anticipated, these substrates were present in all carpel cell walls along the infection path including the youngest growing cell walls in the developing ovary.

The cellulase-gold labeling indicated definite modifications of the molecular structure of the host wall at the interface with

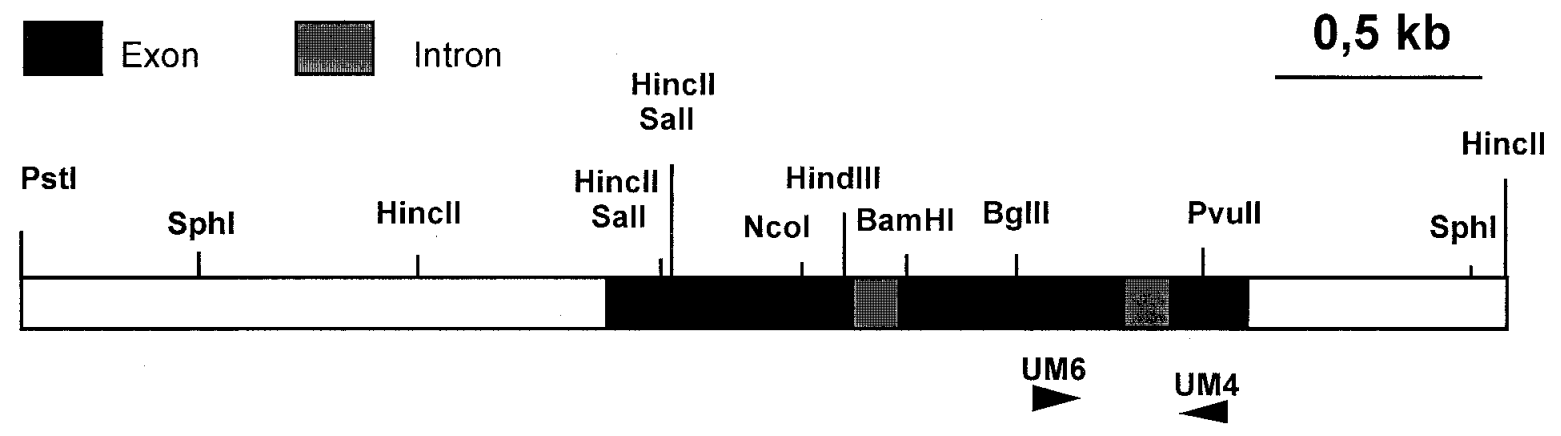

Fig. 2. Restriction map of the part of the 5.6-kb PstI fragment of Claviceps purpurea genomic DNA carrying the cell region. Exons are indicated by black bars, introns are grey, 5'- and 3'-non-coding regions are white. Location of primers UM6 and UM4 used for RT-PCR is indicated by arrow-heads. 
inter- and intracellular hyphae, where plant cell walls were loosened or absent. The lack of cellulase-gold labeling was the second piece of evidence for the potential role of fungal cellulases in ergot pathogenicity, since it most likely indicated a disappearance of cellulose rather than a masking of the binding sites of the cellulase-gold probe. Masking of binding sites due to host induced modifications appears to be rather unlikely. Lignification or phenolic cross linking would reduce the cellulase-gold labeling density as found in the walls of ovary cap trichomes or in the lignified walls of xylem vessels

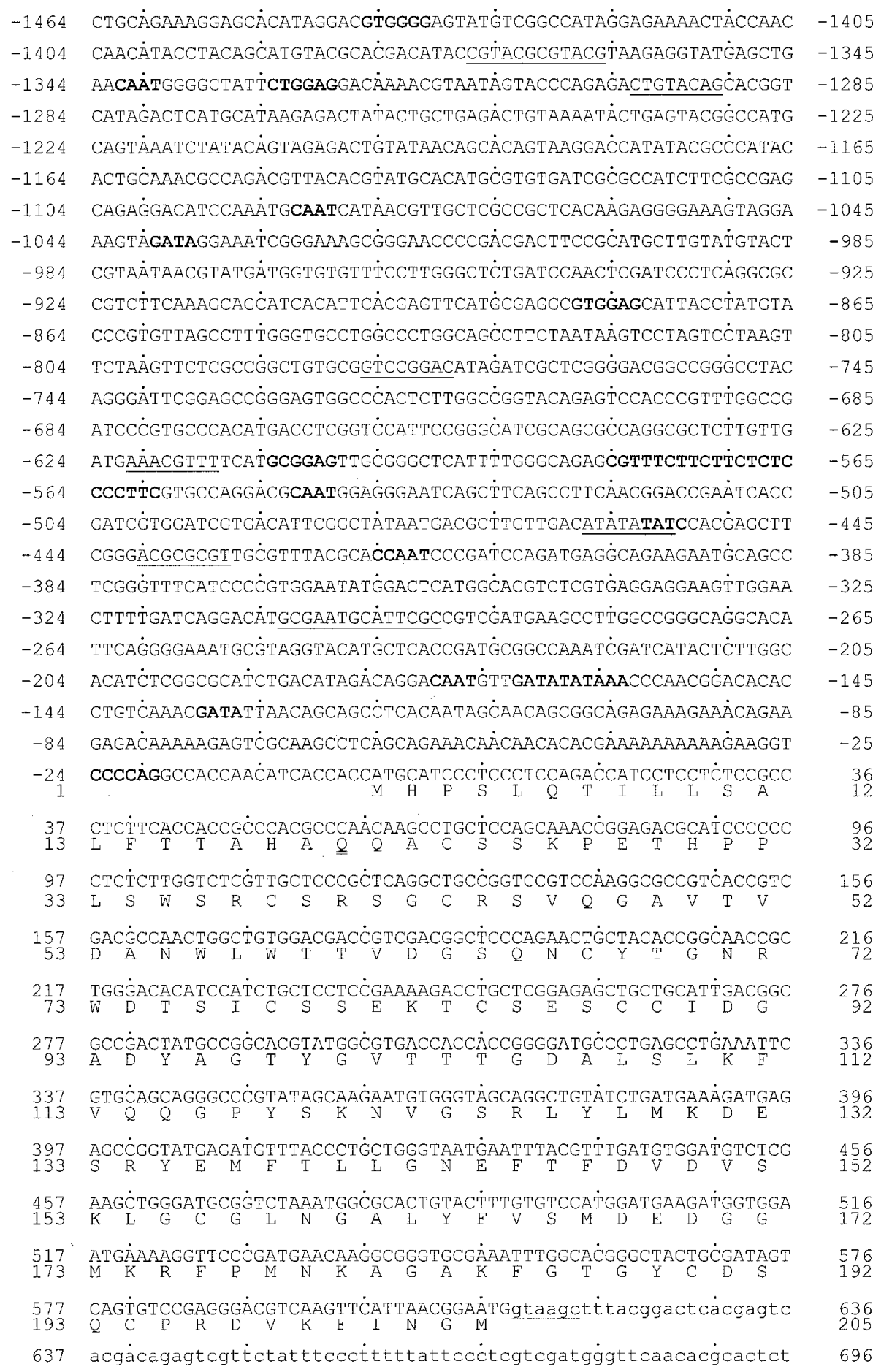

(continued on next page)

Fig. 3. Nucleotide sequence and derived amino acid sequence of cell of Claviceps purpurea. Putative binding sites for regulatory proteins and putative polyadenylation sites are printed in bold letters, intron consensus sequences, and palindrome sequences in the $5^{\prime}$-non-coding region are underlined. The putative first amino acid of the mature protein is underlined twice. Binding sites for primers UM4 and UM6 are indicated. 
in the ovary stalk (not shown). However, a toluidine blue $\mathrm{O}$ staining did not result in the green or turquoise color specific for polyphenols including lignin, but in a red color for polysaccharides which was most intense at the host-pathogen interface (Tenberge et al. 1996). This seems to exclude phenolic cross linking of the polysaccharides at these sites. Furthermore, since the gold labeling indicated a local effect in an infected cell and remained unchanged in all the other wall regions of this cell, one has to postulate a local masking restricted to the narrow cell surface in direct contact to the fungus. Since there are no indications of cellulose masking due to fungal factors despite the binding of secreted cellulases, we concluded that the lack of labeling most likely resulted from enzymatic depolymerization by fungal extracellular cellulases.

For the penetration of living host cells, pressure might be exerted by $C$. purpurea cells as known from other pathogens, e.g. the rice blast fungus (Howard et al. 1991), leading to the invagination of plant cell walls, and causing the reduction of the wall's thickness and consequently of the cellulase-gold label. Nevertheless, the reduction of labeling density shown in cell walls of considerable thickness along intercellular hyphae or in the affected ovary cap zone points to an enzymatic action

Fig. 3. (continued from preceding page)

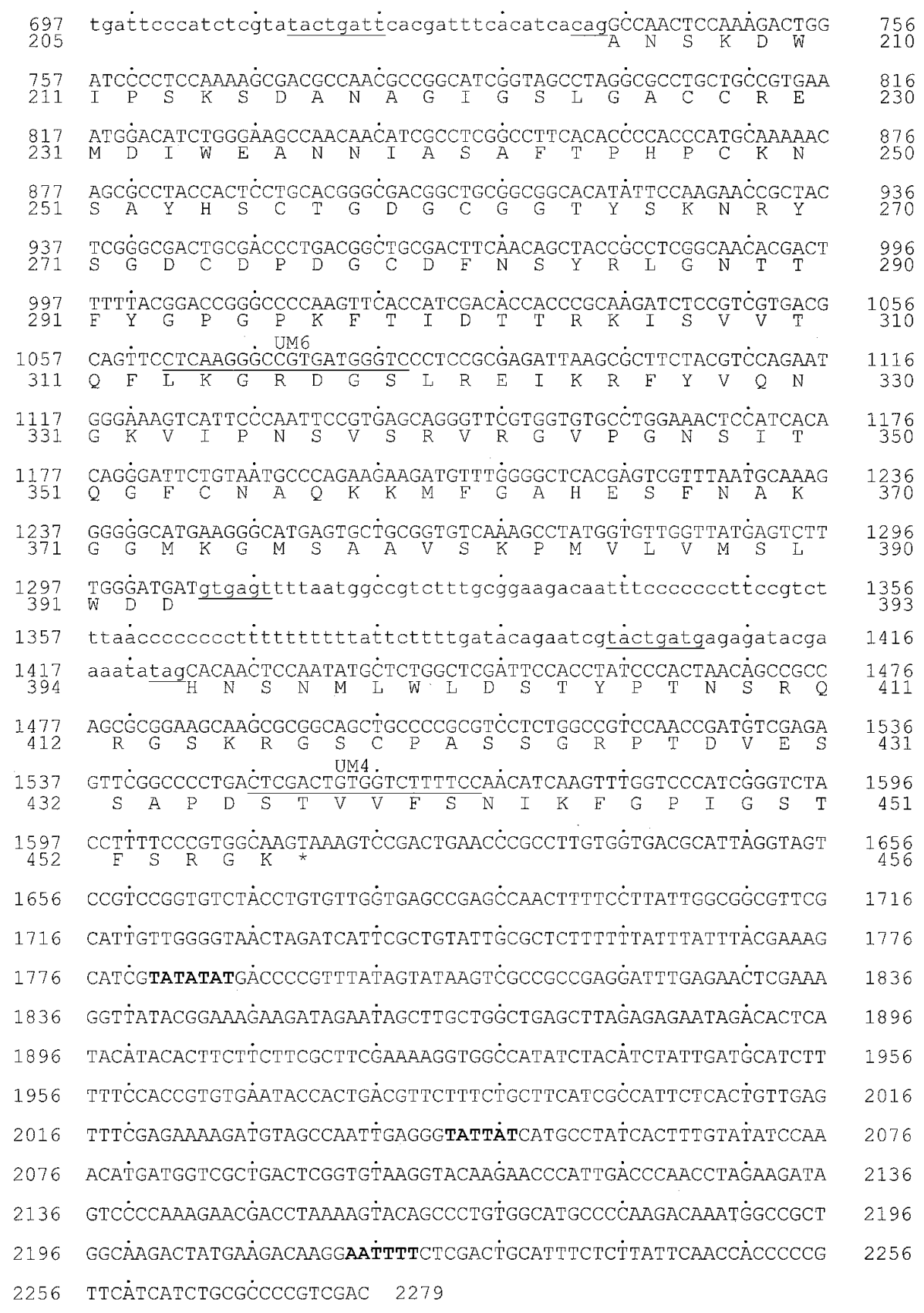

Vol. 10, No. 2, 1997 / 273 
of fungal cellulases occurring at least simultaneously with the application of pressure. But fungal cellulases might not be sufficient to completely degrade the cell walls and, according to Bauer et al. (1977), the cell wall breakdown by fungal cellulases requires an initial attack from pectic enzymes. We re- cently demonstrated the expression of two pectinases in planta together with modification and degradation of pectic components in the host walls at the same sites of the host-pathogen interface analyzed in this work (Tenberge at al. 1996), which suggests that this prerequisite is met by the ergot fungus. A

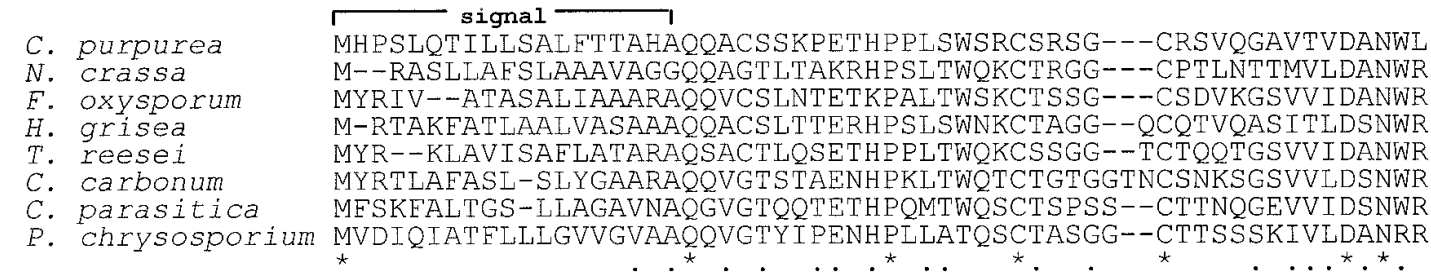

C. purpurea

N. crassa

F. oxysporum

H. grisea

T. reesei

C. carbonum

C. parasitica

P. chrysosporium

C. purpurea

N. Crassa

F. oxysporum

H. grisea

T. reesei

C. carbonum

C. parasitica

P. chrysosporium

C. purpurea

N. crassa

E. oxysporum

H. grisea

T. reesei

C. carbonum

C. parasitica

P. chrysosporium

C. purpurea

N. crassa

F. oxysporum

H. grisea

T. reesei

C. carbonum

C. parasitica

P. chrysosporium

PYSKNVGSRLYLMKDESRYEMETLLGNEETEDVDVSKLGCGENGALYFVSMDEDGGMKRF - - -NVGARAYLMADDTOYOMLELLNOELWFDVDMSNI PCGLNGAL YLSAMDADGGMRKY PYSKNIGSRTYLMENENTYQMFQLLGNEETEDVDVSGIGCGLNGAPHEVSMDEDGGKAKY QHSTNVGSRTYLMDGEDKYQTEELLGNEETEDVDVSNI GCGLNGALYFVSMDADGGLSRY AQ-KNVGARLYLMASDTTYQEFTLLGNEFSEDVDVSQLPCGLNGAI YEVSMDADGGVSKY SFSSNIGSRTYLMETDTKYOMFNI INKEFTFDVDVSKLPCGLNGALYFVEMAADGG IGKS-GKNIGSRTYLMESSTKYHLFDLIGNEFAFDVDLSKLPCGLNGALYFVTMDADGGMAKY --GTNIGSRVELMADDTHYRTFQLINQELAFDVDVSKLPCGLNGALYFVAMDADGGKSKY

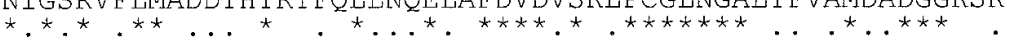

PMNKAGAKFGTGYCDSOCPRDVKFINGMANSKDWIPSKSDANAGIGST,GACCREMDIWEA PTNKAGAKYATGYCDAOCPRDLKYINGIANVEGWTPSTNDAN-GIGDHGSCCSEMDIWEA SGNKAGAKYGTGYCDAQCPRDVKFINGVANSEGWKPSDSDVNAGVGNIGTCCPEMDIWEA PGNKAGAKYGTGYCDAOCPRDIKEINGEANIEGWTGSTNDPNAGAGRYGTCCSEMDIWEA PTNTAGAKYGTGYCDSOCPRDIKFINGOANVEGWEPSSNNANTGIGGHGSCCSEMDIWEA GNNKA GAKYGTGYCDSQCPHDIKEINGKANVEGWNPSDADPNGGAGKIGACCPEMDIWEA STNTAGAEYGTGYCDSQCPRDLKEINGOGNVEGWTPSTNDANAGVGGLGSCCSEMDVWEA GNRAGAKYGTGYCDSQCPRDVQFINGQANVQGWNATS-ATTGTGSYGSCCTELDIWEA

NNIASAFTPHPCKNSAYHSC-TGDGCGGTYSKNRYSGDCDPDGCDENSYRLGNTTEYGPG NKVSTAETPHPCTT IEQHMC-EGDSCGGTYSDDRYGVLCDADGCDFNSYRMGNTTEYGEG NSISTAFTPHPCTKLTQHSC-TGDSCGGTYSSDRYGGTCDADGCDFNAYRQGNKTFYGPG NNMATAFT PHPCT T TGOSRC - FGDSCGGTYSNFRYAGVCDPDGCDFNSYROGNKTEYGKG NS I SEAITPHPCTTVGQEIC-EGDGCGGTYSDNRYGGTCDPDGCDWNPYRIGNTSEYGPG NSISTAYT PHPCRGVGLQECSDAASCGD--GSNRYDGQCDKDGCDFNSYRMGVKDEYGPG NSMDMAYTPHPCETAAOHSC-NADECGGTYSSSRYAGDCDPDGCDWNPFRMGNKDFYGSG NSNAAAT TPHTCTNNAQTRCS-GSNCTSN------TGFCDADGCDFNSERIGNTTELGAG

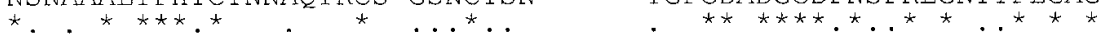
GECNAQKKMFGAHESFNAKGGMKGMSAAVSKPMVLVMSLWDDHNSNMIWLDSTYPTNSRQ SECKSOKTAFGDIDDFNKKGGIKOMGKALAOAMVLVMSIWDDHAANMILWLDSTYPV-PKV DFCSKOKSVEGDIDDFSKKGGWNGMSDALSAPMVLVMSLWHDHHSNMIWLDSTYPT-DST DWCDRQKVAFGDIDDFNRKGGMKQMGKALAGPMVLVMSIWDDHASNMLWLDSTFPV-DAA DYCTAEEAEFGG - SSESDKGGLTQFKKATSGGMVLVMSLWDDYYANMLWLDSTYPTNETS SECTAOKKAFGDTSSEAALGGINEMGASLARGHVLIMSLWGDHAVNMLWLDSTYPTDADP DECKAOKVEFNDTDVFSEKGGIAQMGAGMADGMVLVMSLWDDH YANMLWLDSTYPVDADA PECSQQKKAFIETNY FAQHGGLAQLGQALRTGMVLAFSISDDPANHMLWLDSNFP S SANP $* * * * * * \ldots *$

C. purpurea
N. crassa
F. oxysporum
$H$. grisea
T. reesei
C. carbonum
C. parasitica
P. chrysosporium

( hinge --RGSKRGSCPASSGRPTDVESSAPDSTVVESNIKEGPIGSTESRGK--------- --PGAYRGSGPTTSGVPAEVDANAPNSKVAFSNIKEGHLGISPESGGSSGTPPSNPSSSA -KVGSQRGSCATTSGKPSDLERDVPNSKVSESNIKEGPIG-STYKS---------DGTTP GKPGAERGACPTTSGVPAEVEAEAPNSNVVESNIREGPIG-STVAGLPGAGNGGNNGGNP STPGAVRGSCSTSSGVPAQVESQSPNAKVTESNIKFGPIG------- STGNPSGGNPPG SKPGAARGTCPTTSGKPEDVEKNSPDATVVYSNIKFGPIGSTFAQPA---------- SSPGKQRGTCATTSGVPADVESSDASATVIESNIKEGPIGATY--------------

57

55

55 57 56

C. purpurea

N. crassa

- substrate binding domain $--1,-1-1-1$

F. oxysporum

H. grisea

T. reesei

C. carbonum

C. parasitica

P. chrysosporium

SPTSSTAKOSSTSTASNPSGTGAAHWAQCGGIGESGPTTCPEPYTCAKDHDIYSQCV NPPASSSTTGSSTPTNPPAGS-VDQWGQCGGQNYSGPTTCKSPETCKKINDEYSQCQ PPPTTTTSSAPATTTTASAGPKAGRWQQCGGIGETGPTQCEEPYICTKLNDWYSQCL GNRGTTTTRRPATTTGSSPGPTQSHYGQCGGIGYSGPTVCASGTTCQVLNPYYSQCL

Fig. 4. Comparison of parts of the derived amino acid sequence of cell from Claviceps purpurea with the corresponding sequences of cellulases from various fungi. Amino acids conserved in all proteins are marked by an asterisk, a point indicates residues which are filled by functional analogous amino acids in all proteins. The positions of signal peptide, hinge, and substrate binding domain are indicated; the catalytic domain comprises the region between signal peptide and hinge. For references see text and legend to Figure 8. 
controlled synergistic utilization of several different cell wall degrading enzymes appears to be an important and effective mechanism for the colonization by biotrophic fungi, because a graded action of hydrolytic enzymes has been described for other strictly biotrophic pathogens (Mendgen and Deising 1993).

\section{Structural aspects of cell.}

Sequence data are now available for a large number of fungal cellulases. They have been grouped into several families according to homologies between specific amino acid sequences (Henrissat et al. 1989; for a recent review see $\mathrm{Ne}-$ valainen and Penttilä 1995). The C. purpurea CEL1 gene product shows significant homology to family $\mathrm{C}$ cellulases, which include both endoglucanases and cellobiohydrolases. Since a biochemical evaluation of the cleavage specificity of CEL1 is not possible due to the extremely low level of expression, sequence comparison represents the only possibility to draw conclusions on the type of enzyme probably encoded by cell at present. A tree analysis based on the amino acid sequences of the catalytic domains of fungal cellulases belonging to family $\mathrm{C}$ groups $C E L 1$ of $C$. purpurea together with putative cellobiohydrolases of $H$. grisea and $F$. oxysporum, far away from the endoglucanase EGI from Trichoderma reesei (Fig. 8). More convincing arguments that cell might indeed code for a cellobiohydrolase are based on data published by Divne et al. (1994) on the 3-D structure of CBHI of T. reesei. They postulate that the catalytic domain of the enzyme forms a hydrophilic tunnel which takes up a free end of a cellulose molecule and cleaves off the terminal cellobiose. Endo-cutting enzymes lack parts of the sequence, which leads to the forma-

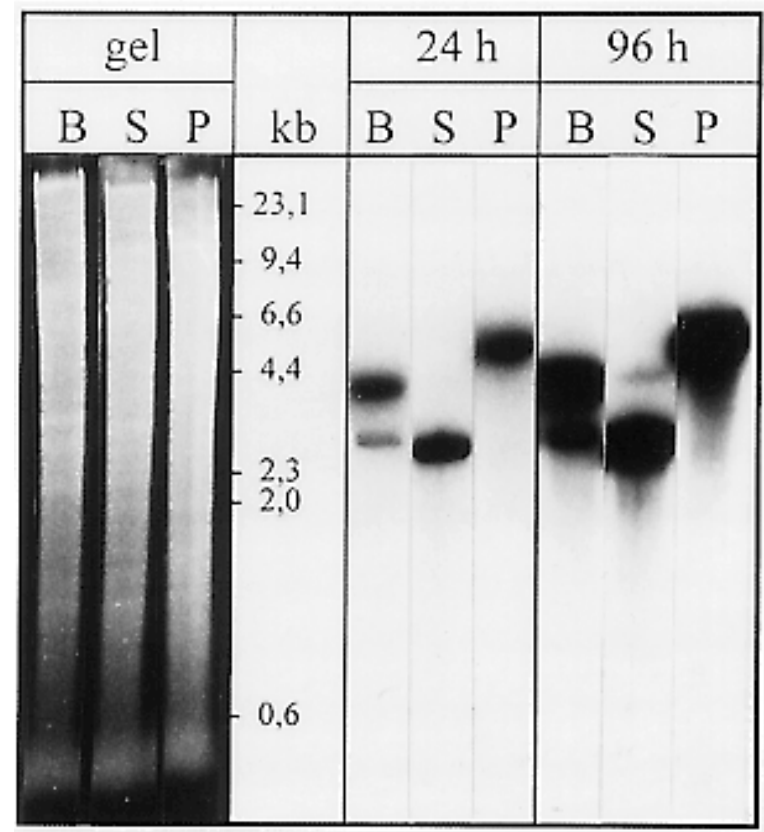

Fig. 5. Determination of copy number of cell in strain T5 of Claviceps purpurea. Genomic DNA of strain T5 was digested with SphI (S), PstI (P), and BamHI (B), respectively, separated in an agarose gel, blotted on Nylon membrane, and hybridized to a ${ }^{32} \mathrm{P}-$ labeled 2.1-kb HincII fragment carrying most of the cell coding region (see Fig. 2). Hybridization conditions were moderately stringent $\left(55^{\circ} \mathrm{C}\right)$; exposure times were 24 and $96 \mathrm{~h}$. tion of an open groove, allowing binding of internal parts of the cellulose molecule. Comparison of the amino acid sequences of $C B H I$ of $T$. reesei and $C E L 1$ of $C$. purpurea shows that CELI contains all amino acid residues which are postulated to be essential for the tunnel formation, strongly indicating that CEL1 represents an exo-cutting enzyme, a cellobiohydrolase.

A special feature of the CEL1 structure, which is distinct from the closely related $H$. grisea and $F$. oxysporum enzymes, is the lack of a substrate binding domain. The classical 3-D-
A

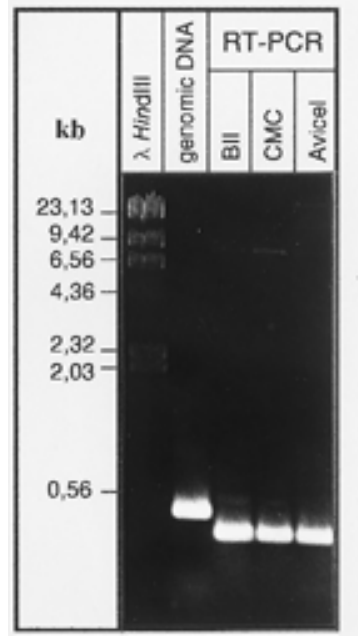

B

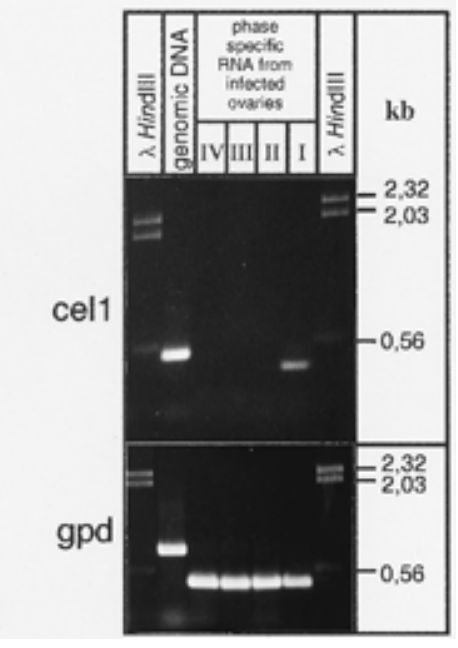

Fig. 6. Expression analysis of cell by RT-PCR, using primers UM4 and UM6 and template RNA from (A) axenic culture grown for 3 days on cellophane membranes then transferred to solid medium containing either Avicel or CMC or BII medium and from (B) stages I to IV of rye infection during parasitic culture (see Fig. 6). Expression analysis of gpd by RT-PCR for control reactions using the same templates and the primers GPD1 and GPD2 (B).

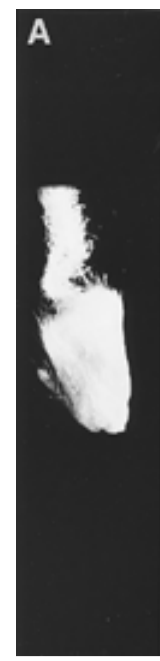

stage I

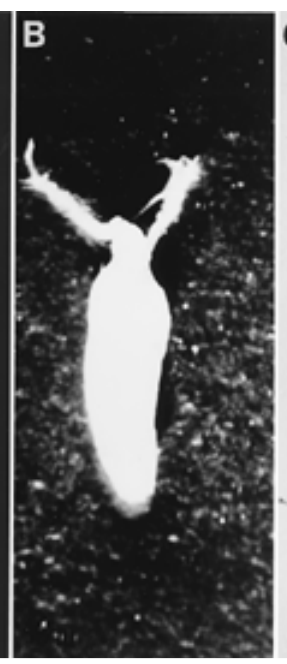

stage II

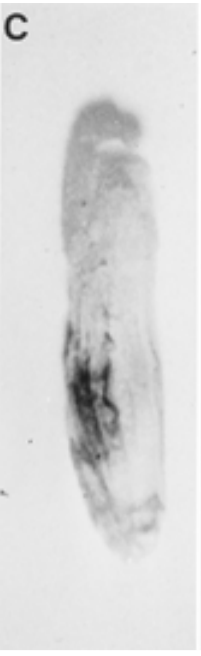

stage III

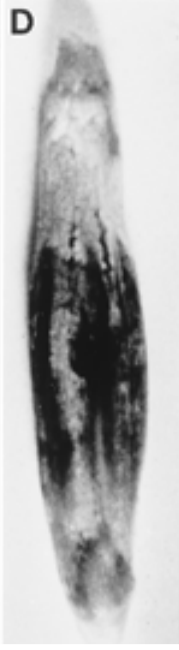

stage IV
Fig. 7. Stages of infection of Claviceps purpurea on rye. A, Young infected ovary during the initial colonization phase without major outer symptoms, stage I, up to 5 days postinoculation (dpi); $\mathbf{B}$, honeydew producing sphacelia, stage II, $10 \mathrm{dpi}$; $\mathbf{C}$, late sphacelium, beginning of sclerotia formation, stage III, $15 \mathrm{dpi}$; D, sclerotium, stage IV, 20 dpi. 
structure of a cellulase (and most glycosylhydrolases involved in depolymerization of polysaccharides) contains a catalytic domain linked by a hinge to a substrate binding domain (SBD). The function of this SBD probably is to support the positioning of the catalytic domain, but it might also loosen the structure of the substrate, rendering it more accessible for the catalytic domain (see Nevalainen and Penttilä 1995). Proteolytic cleavage of SBD of $C B H I$ and $C B H I I$ from T. reesei reduces their enzymatic activity on crystalline cellulose without affecting the activity on soluble cellulose (Tomme et al. 1988). Family C contains three other members of these truncated, shorter cellobiohydrolase forms: CELI from Cochliobolus carbonum (Sposato et al. 1995), CBHI from P. chrysosporum (Covert et al. 1991) and CBH-1 from Cryphonectria parasitica (Wang and Nuss 1995). Since these enzymes have not yet been purified and characterized, nothing is known about special features which might be correlated with the loss of SBD. The dendrogram (Fig. 8) shows that CEL1 has more homology with $\mathrm{CBH}$ enzymes containing a SBD than with the other truncated versions indicating that either loss or gain of the SBD have occurred several times independently. It is an open question whether the cellulases with a SBD derived from the shorter ones or vice versa.

\section{Expression of cell.}

The low transcriptional activity of cell (as estimated from Northern analyses) in axenic culture corresponds well to the extremely low overall cellulolytic acitivity. As yet no conditions could be defined in which $C$. purpurea secretes larger amounts of cellulases: Preliminary analyses gave no hints for the involvement of nitrogen or glucose repression or substrate induction. However, the RT-PCR data presented in this paper show that the gene is expressed under different conditions in axenic cultures and in the first phase of rye infection during parasitic culture. The mechanism of induction or repression of activity remains unclear. A structural analysis of the putative promoter sequence of cell (Fig. 3) reveals several features which might be important for regulation of the gene: (i) Palindromes of at least 8 nucleotides occur at positions $-308,-440$, $-462,-621,-781,-1298,-1372$; they might be involved in binding of regulatory proteins as seen in Fusarium solani $\mathrm{f}$. sp. pisi (Kämper et al. 1994), where such palindromes are involved in the regulation of the cutinase gene. (ii) Putative binding sites for a regulatory element of the C-catabolite repression system are present, which are comparable to those of the CREA protein of Aspergillus nidulans (Cubero and Scazzocchio 1994). The CREA binding consensus sequence is 5'SYGGRG-3'; efficient binding probably requires the presence of two closely linked consensus sequences, as has been shown for the xylanase gene $x y n 1$ of $T$. reesei (Mach et al. 1996). The cell upstream region contains five putative CREA binding sites, all with more than 30-bp distance; so it is uncertain whether cell really is under the control of a CREAhomologous protein. (iii) Putative binding sites for positively acting regulatory proteins of the N-catabolite system are present. In A. nidulans, Penicillium chrysogenum, and Neurospora crassa, genes coding for enzymes which are required for assimilation of other nitrogen sources than ammonium are under the control of positive regulatory genes (areA: Caddick 1992; nre: Haas and Marzluf 1995; nit2: Chiang and Marzluf 1994); consensus binding sequences for the respective proteins always include GATA motifs, in most cases at least two of them in tandem or reverse orientation. The cell promoter contains four GATA motifs (see Fig. 3); those at position -168 and 135 might represent a binding site for an AREA-homologous protein, as suggested by the minimal distance between them. Nitrogen starvation could play an important role in the induction of pathogenesis-related genes in $C$. purpurea. Also in

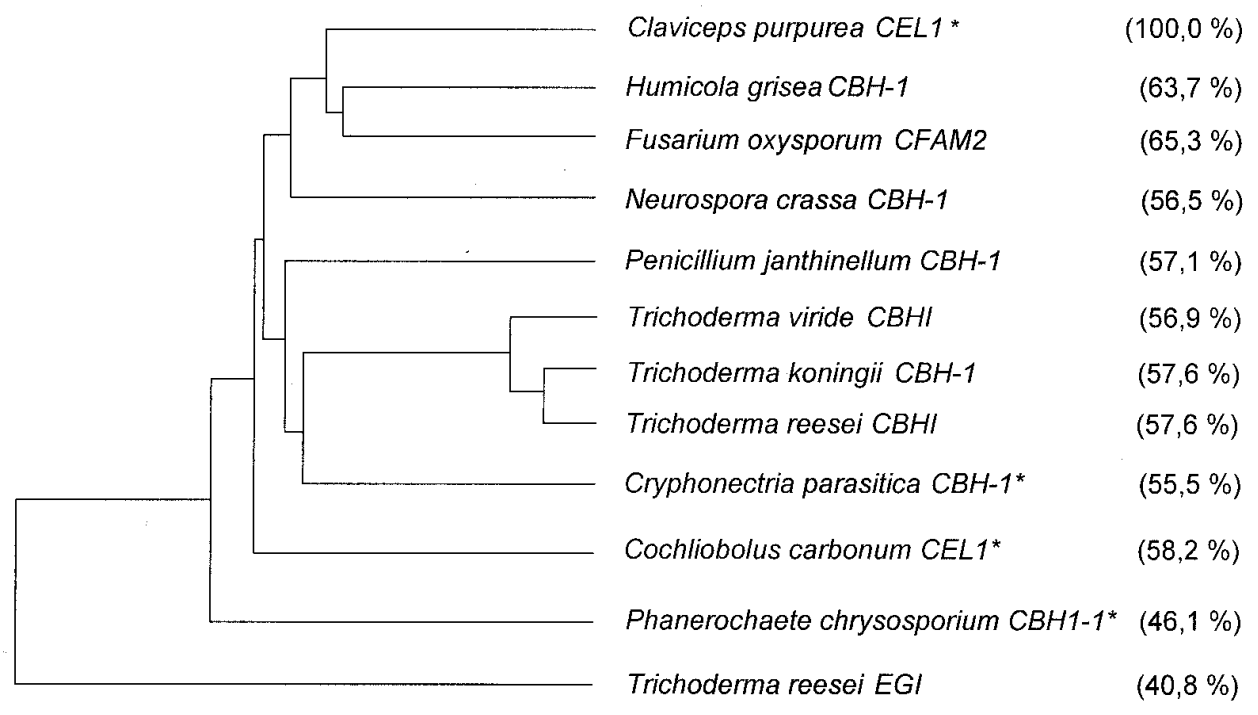

Fig. 8. Dendrogram based on the amino acid sequences of the catalytic domains of $C E L 1$ and various other fungal enzymes belonging to family $\mathrm{C}$ of cellulases: $C B H-1$ from Humicola grisea (Azevedo et al. 1990), CFAM2 from Fusarium oxysporum (Sheppard et al. 1994), CBH-1 from Neurospora crassa (Taleb and Radford 1995), CBH-1 from Penicillium janthinellum (Koch et al. 1993), CBHI from Trichoderma viride (Cheng et al. 1990), CBH-1 from Trichoderma koningii (Wey et al. 1994), CBHI from Trichoderma reesei (Shoemaker et al. 1983), CBH-1 from Cryphonectria parasitica (Wang and Nuss 1995), CEL1 from Cochliobolus carbonum (Sposato et al. 1995), CBH1-1 from Phanerochaete chrysosporium (Covert et al. 1992), EGI from Trichoderma reesei (Penttilä at al. 1986). Enzymes which do not contain a substrate binding domain are marked by an asterisks. The degree of homology (percentage of identical amino acids) to CEL1 is given in brackets. 
Phytophthora infestans (Pieterse et al. 1994) and in Cladosporium fulvum (Van den Ackerveken et al. 1994), in planta induction of interaction-related genes by nitrogen-starvation could be demonstrated. (iv) A CCAAT motif at position -420 corresponds to a putative sophorose induction domain of the $\mathrm{CBH} 2$ gene promoter of Trichoderma reesei (Seiboth et al. 1996).

A detailed analysis of the regulation of cell in axenic culture could be achieved either by quantitative RT-PCR (which has many pitfalls) or by Northern experiments using transformants carrying multiple copies of cell.

Though the RT-PCR technique as applied here is not quantitative, the detection of cell-derived products only with RNA of phase I indicates a higher level of transcription of cell in the first days of infection. Though cell is probably not the only cellulase gene of $C$. purpurea, this phase-specific transcription could point to a special role of this enzyme in the colonization of host tissue. A comparable short cellulase gene has been recently disrupted in $C$. carbonum (Sposato et al. 1995) without any significant effect on pathogenicity; however, in a biotrophic, balanced interaction like $C$. purpurea with Secale cereale, loss of such an enzyme might have a more drastic effect. Disruption of cell in C. purpurea will be necessary to shed more light on the role of CEL1 in the colonization process and the function of cellulases in general. Even if disruption of cell proves to have no major effect on pathogenicity, a detailed cytological analysis will show whether the fungus can colonize the rye ovary while lacking this enzyme activity. In this case, the loss of cellulose labeling during infection reported here should not be observable with the deletion mutants; however, if cellulose is still degraded by these strains, cellulase genes other than cell are active in planta.

\section{MATERIALS AND METHODS}

\section{Strains and culture conditions.}

A standard field isolate of $C$. purpurea (Fr.) Tul., strain T5 isolated from rye (Secale cereale L.; Hohenheim, Germany), was used for all studies. Mycelia were cultivated in $100 \mathrm{ml}$ of BII medium (Esser and Tudzynski 1978) in Erlenmeyer flasks of $300-\mathrm{ml}$ capacity at $28^{\circ} \mathrm{C}$ on a rotary shaker at $150 \mathrm{rpm}$. For transcription analysis, mycelia were grown on cellophane membranes for 3 days, subsequently transferred on solid medium containing $1 \%(\mathrm{wt} / \mathrm{vol})$ crystalline cellulose (Avicel) or $1 \%(\mathrm{wt} / \mathrm{vol}) \mathrm{CMC}$ as carbon source, and harvested after $24 \mathrm{~h}$. E. coli DH5 $\alpha$ (Hanahan 1983) was used for standard cloning procedures. Lambda clones were propagated in E. coli strain K 803 (Wood 1966).

\section{Parasitic culture on rye plants.}

Rye plants were cultivated in growth chambers as described by Smit and Tudzynski (1992) and inoculated with conidia from axenic cultures of $C$. purpurea T5 as described elsewhere (Tenberge et al. 1996).

\section{Molecular techniques.}

Standard molecular genetic methods were performed according to Sambrook et al. (1989) and Ausubel et al. (1987), Northern analysis was done as described by Church and Gilbert (1984). Isolation of DNA for Southern and PCR analysis was performed according to Cenis (1992). For expression analysis during the parasitic cycle of ergot, RNA was prepared according to Chambers and Russo (1986) from infected ovaries collected at various stages, immediately frozen and lyophylized. RNA was identically prepared from cellophane grown mycelia for expression analysis in axenic culture.

For molecular cloning, a genomic EMBL 3 library of strain T5 (Smit and Tudzynski 1992) was screened by plaque filter hybridization according to Sambrook et al. (1989), using a fragment of the $C B H I$ gene of Trichoderma reesei as a probe (a 720-bp EcoRI fragment of vector pCBHI, Shoemaker et al. $1983)$ under moderately stringent conditions $\left(55^{\circ} \mathrm{C}\right)$. Fiftythousand plaques were screened in a first round. Positive clones were plated again and purified as single plaques. DNA was extracted and characterized by restriction analysis and Southern hybridization using the cbhI probe. For DNAsequencing, the T7-sequencing kit and the nested-deletion kit (Pharmacia Biotech, Freiburg, Germany) were used. Computer analysis of the sequence was done using HUSAR (EMBL, Heidelberg, Germany) and PC/Gene (Intelligenetics, Inc., Mountain View, CA).

For RT-PCR, primers were used as follows: UM4: 5'-GGA AAA GAC CAC AGT CGA G-3’, UM6: 5'-CTC AAG GGC CGT GAT GGG TC-3', GPD1: 5'-CAA CGA CCC TTT CAT CGA C-3', and GPD2: 5'-GTG TAC GAG TGG ACA GTG$3^{\prime}$. Data in square brackets indicate the conditions for the gpd control. One microgram of RNA and $200 \mathrm{ng}$ of primer UM4 [GPD1] were heated $10 \mathrm{~min}$ at $70^{\circ} \mathrm{C}$ and then cooled on ice. For the RT reaction, dNTPs ( $1 \mathrm{mM}$ each), $1 \times$ PCR buffer $(10$ $\mathrm{mM}$ Tris- $\mathrm{HCl}, \mathrm{pH} 9.0,50 \mathrm{mM} \mathrm{KCl}, 1.5 \mathrm{mM} \mathrm{MgCl}_{2}, 0.01 \%$ [wt/vol] gelatin, $0.1 \%$ Triton $\mathrm{X}-100$ ) and 100 units of RNA guard (Pharmacia Biotech, Freiburg, Germany) were added. After a preincubation step of $2 \mathrm{~min}$ at $42^{\circ} \mathrm{C}, 200 \mathrm{U}$ of M-MLV reverse transcriptase (Gibco BRL Life Technologies, Eggenstein, Germany) were added. After $1 \mathrm{~h}$ the reaction was stopped $\left(95^{\circ} \mathrm{C}, 10 \mathrm{~min}\right.$, then ice). For control reactions, $100 \mathrm{ng}$ of genomic DNA were used as template for the PCR. For the PCR amplification, the reaction mixture contained one half of the RT reaction, $200 \mathrm{ng}$ of each primer UM4 and UM6 [GPD1 and GPD2], $0.1 \mathrm{U}$ Taq-polymerase and $2 \mathrm{mM}$ nucleotides in Taqbuffer. The PCR run started with the first cycle for 4 min at $94^{\circ} \mathrm{C}, 40 \mathrm{~s}$ at $56^{\circ} \mathrm{C}\left[59^{\circ} \mathrm{C}\right]$, and $2 \mathrm{~min}$ at $72^{\circ} \mathrm{C}$; followed by 34 cycles of $25 \mathrm{~s}$ at $94^{\circ} \mathrm{C}, 40 \mathrm{~s}$ at $56^{\circ} \mathrm{C}\left[59^{\circ} \mathrm{C}\right]$, and $2 \mathrm{~min}$ at $72^{\circ} \mathrm{C}$, and ended with a last cycle of $4 \mathrm{~min}$ at $72^{\circ} \mathrm{C}$.

\section{Transmission electron microscopy (TEM) and enzyme-gold cytochemistry.}

For standard TEM, selected ovaries were cut out of florets in a drop of fixative, consisting of $3 \%$ ( vol/vol) glutaraldehyde in $25 \mathrm{mM}$ sodium phosphate buffer, pH 7.0 (NaPB). Following vacuum infiltration, the fixative was changed and fixation continued up to $4 \mathrm{~h}$ at $4^{\circ} \mathrm{C}$. The specimens were postfixed with $2 \%$ (wt/vol) $\mathrm{OsO}_{4}$ in $\mathrm{NaPB}$ for $2 \mathrm{~h}$ at room temperature, dehydrated in a graded ethanol series, passed through propylene oxide, thoroughly infiltrated in epoxy resin (Spurr 1969) and finally polymerized at $70^{\circ} \mathrm{C}$ for $20 \mathrm{~h}$. Ultrathin sections were cut with a Reichert-Jung Ultracut $\mathrm{E}$ microtome using diamond knives and collected on Pioloform-coated nickel grids. Sections were contrasted with uranyl acetate and lead citrate and observed with a Siemens Elmiskop 102 electron microscope. 
For preparation of cellulase-gold particles, a 1,4-(1,3;1,4)$\beta$-D-glucan-4-glucanohydolase (EC 3.2.1.4) purified from Trichoderma viride (Onozuka, Yakult, Japan) was linked to colloidal gold as described elsewhere (Tenberge 1992). Successful linkage to gold particles and purity of their protein envelope was tested by SDS-PAGE of sedimented particles after several washings in distilled water. Endo- $\beta$-1,4-glucanase activity of the cellulase-gold particles was proven in a CMCagarose plate assay.

For labeling of cellulose, ultrathin sections were quenched with $0.05 \mathrm{M}$ citrate buffer, $\mathrm{pH} 5.0$, containing $1 \%$ bovine serum albumin (Sigma, Deisenhofen, Germany) and $0.5 \%$ gelatin for $5 \mathrm{~min}$, floated on cellulase-gold sol (1:10 diluted) for $15 \mathrm{~min}$ and conventionally contrasted. Several labeling controls were perfomed including preincubation of the gold sol with CMC, which reduced the labeling to background level.

\section{ACKNOWLEDGMENTS}

We wish to thank C. P. Kubicek (University of Technology, Vienna, Austria) for providing us with $c b h$ clones from Trichoderma; E. Hansen for performing the agarose plate assay; K. Hölter for technical assistance; S. Moore for critical reading the manuscript; and A. Kammerahl for typing the manuscript. This research was financially supported by the Deutsche Forschungsgemeinschaft (DFG, Germany).

\section{LITERATURE CITED}

Ausubel, F. M., Brent, R., Kingston, R. E., Moore, D. D., Seidmann, J. G., Smith, J. A., and Struhl, K. 1987. Current Protocols in Molecular Biology. John Wiley \& Sons, New York.

Azevedo, M. de O., Felipe, M. S. S., Astolfi-Filho, S., and Radford, A. 1990. Cloning, sequencing and homologies of the cbh-1 (exoglucanase) gene of Humicola grisea var. thermoidea. J. Gen. Microbiol. 136:2569-2576.

Ballance, D. J. 1991. Transformation systems for filamentous fungi and an overview of fungal gene structure. Pages 1-29 in: Molecular Industrial Mycology: Systems and Applications for Filamentous Fungi. S. A. Leong and R. M. Berka, eds. Marcel Dekker, New York.

Bauer, W. D., Bateman, D. F., and Whalen, C. H. 1977. Purification of an endo- $\beta$-1,4-galactanase produced by Sclerotinia sclerotiorum: Effects on isolated plant cell walls and potato tissue. Phytopathology 67:862-868.

Brockmann, B., Smit, R., and Tudzynski, P. 1992. Characterization of an extracellular $\beta$-1,3-glucanase of Claviceps purpurea. Physiol. Mol. Plant Pathol. 40:191-201.

Caddick, M. X. 1992. Characterization of a major Aspergillus regulatory gene, areA. Pages 141-152 in: Molecular Biology of Filamentous Fungi. Proceedings of the EMBO Workshop, Berlin. U. Stahl and P. Tudzynski, eds. VCH Verlagsgesellschaft mbH, Weinheim.

Campbell, W. P. 1958. Infection of barley by Claviceps purpurea. Can. J. Bot. 36:615-619.

Carpita, N. C., and Gibeaut, D. M. 1993. Structural models of primary cell walls in flowering plants: Consistency of molecular structure with the physical properties of the walls during growth. Plant J. 3:1-30.

Cenis, J. L. 1992. Rapid extraction of fungal DNA for PCR amplification. Nucleic Acids Res. 20:2380.

Chambers, A. A., and Russo, V. E. A. 1986. Isolating RNA is easy and fun. Fungal Genet. Newslett. 33:22-23.

Cheng, C., Tsukagoshi, N., and Udaka, S. 1990. Nucleotide sequence of the cellobiohydrolase gene from Trichoderma viride. Nucleic Acids Res. 18:5559.

Chiang, T. Y., and Marzluf, G. A. 1994. DNA recognition by the NIT2 nitrogen regulatory protein: Importance of the flanking sequences upon NIT2-binding. Biochemistry 33:576-582.

Church, G. M., and Gilbert W. 1984. Genomic sequencing. Proc. Natl. Acad. Sci. USA 81:1991-1995.

Covert, S. F., van den Wymelenberg, A., and Cullen, D. 1992. Structure, organization, and transcription of a cellobiohydrolase gene cluster from Phanerochaete chrysosporium. Appl. Environ. Microbiol. 58:2168-2175.

Cubero, B., and Scazzocchio, C. 1994. Two different, adjacent and divergent zinc finger binding sites are necessary for CREA-mediated carbon catabolite repression in the proline gene cluster of Aspergillus nidulans. EMBO J. 13:407-415.

Divne, C., Ståhlberg, J., Reinikainen, T., Ruohonen, L., Petterson, G., Knowles, J. K. C., Teeri, T. T., and Jones, T. A. 1994. The threedimensional crystal structure of the catalytic core of cellobiohydrolase I from Trichoderma reesei. Science 265:524-528.

Esser, K., and Tudzynski, P. 1978. Genetics of the ergot fungus Claviceps purpurea. I. Proof of a monoecious life cycle and segregation patterns for mycelial morphology and alkaloid production. Theor. Appl. Genet. 53:145-149.

Haas, H., and Marzluf, G. A. 1995. NRE, the major nitrogen regulatory protein of Penicillium chrysogenum, binds specifically to elements in the intergenic promoter regions of nitrate assimilation and penicillin biosynthetic gene clusters. Curr. Genet. 28:177-183.

Hanahan, D. 1983. Studies on transformation of Escherichia coli with plasmids. J. Mol. Biol. 166:557-563.

Henrissat, B., Claeyssens, M., Tomme, P., Lemesle, L., and Mornon, J.P. 1989. Cellulase families revealed by hydrophobic cluster analysis. Gene 81:83-95.

Howard, R. J., Bourett, T. M., and Ferrari, M. A. 1991. Infection by Magnaporthe: An in vitro analysis. Pages 251-264 in: Electron Microscopy of Plant Pathogens. K. Mendgen and D. E. Lesemann, eds. Springer-Verlag, Berlin.

Jungehülsing, U., Arntz, C., Smit, R., and Tudzynski, P. 1994. The Claviceps purpurea glyceraldehyde-3-phosphate dehydrogenase gene: Cloning, characterization and use for improvement of a dominant selection system. Curr. Genet. 25:101-106.

Kämper, J. T., Kämper, U., Rogers, L. M., and Kolattukudy, P. E. 1994. Identification of regulatory elements in the cutinase promoter from Fusarium solani f. sp. pisi (Nectria haematococca). J. Biol. Chem. 269:9195-9204.

Koch, A., Weigel, C. T. O., and Schulz, G. 1993. Cloning, sequencing, and heterologous expression of a cellulase-encoding cDNA (cbhl) from Penicillium janthinellum. Gene 124:57-65.

Mach, R. L., Strauss, J., Zeilinger, S., Schindler, M., and Kubicek, C. P. 1996. Glucose repression of xyn1 (xylanase I encoding gene) expression by Crel in Trichoderma reesei requires binding of a protein complex to an inverted repeat of the Crel consensus sequence. Fungal Genet. Newsletter 43B:66.

Mendgen, K., and Deising, H. 1993. Infection structures of fungal plant pathogens. A cytological and physiological evaluation. New. Phytol. 124:193-213.

Nevalainen, H., and Penttilä, M. 1995. Molecular biology of cellulolytic fungi. Pages 303-319 in: The Mycota II, Genetics and Biotechnology. U. Kück, ed. Springer-Verlag, Berlin, Heidelberg.

Penttilä, M., Lehtovaara, P., Nevalainen, H., Bhikhabhai, R., and Knowles, J. 1986. Homology between cellulase genes of Trichoderma reesei: Complete nucleotide sequence of the endoglucanase I gene. Gene 45:253-263.

Pieterse, C. M. J., Derksen, A. M. C. E., Folders, J., and Govers, F. 1994. Expression of the Phytophthora infestans ipiB and ipiO genes in planta and in vitro. Mol. Gen. Genet. 244:269-277.

Saloheimo, M., Lehtovaara, P., Penttilä, M., Teeri, T. T., Ståhlberg, J., Johansson, G., Pettersson, G., Claeyssens, M., Tomme, P., and Knowles, J. K. C. 1988. EGIII, a new endoglucanase from Trichoderma reesei: The characterisation of both gene and enzyme. Gene 63:11-21.

Sambrook, J., Fritsch, E. F., and Maniatis, T. 1989. Molecular Cloning: A Laboratory Manual, 2nd ed. Cold Spring Harbor Laboratory Press, Cold Spring Harbor, New York.

Seiboth, B., Rauscher, R., Stangl, H., Gruber, F., Mach, R. L., and Kubicek, C. P. 1996. A CCAAT-Box mediates sophorose-induction of $c b h 2$ (cellobiohydrolase II-encoding)-gene expression in the filamentous fungus Trichoderma reesei. Fungal Genet. Newslett. 43B:80.

Shaw, B. I., and Mantle, P. G. 1980. Host infection by Claviceps purpurea. Trans. Br. Mycol. Soc. 75:77-90.

Sheppard, P. O., Grant, F. J., Oort, P. J., Sprecher, C. A., Foster, D. C., Hagen, F. S., Upshall, A., McKnight, G. L., and Ohara, P. J. 1994. The use of conserved cellulase family-specific sequences to clone cellulase homologue cDNAs from Fusarium oxysporum. Gene 150:163-167. 
Shoemaker, S., Schweickart, V., Ladner, M., Gelfand, D., Kwok, S., Myambo, K., and Innis, M. 1983. Molecular cloning of exocellobiohydrolase I derived from Trichoderma reesei strain L27. Bio/Technology 1:691-696.

Smit, R., and Tudzynski, P. 1992. Efficient transformation of Claviceps purpurea using pyrimidine auxotrophic mutants cloning of the OMP decarboxylase gene. Mol. Gen. Genet. 234:297-305.

Sposato, P., Ahn, J.-H., and Walton, J. D. 1995. Characterization and disruption of a gene in the maize pathogen Cochliobolus carbonum encoding a cellulase lacking a cellulose binding domain and hinge region. Mol. Plant-Microbe Interact. 8:602-609.

Spurr, A. R. 1969. A low-viscosity epoxy resin embedding medium for electron microscopy. J. Ultrastruct. Res. 26:31-43.

Taleb, F., and Radford, A. 1995. The cellulase complex of Neurospora crassa: cbh-1 cloning, sequencing and homologies. Gene 161:137138.

Teeri, T. T., Lehtovaara, P., Kauppinen, S., Salovuori, I., and Knowles, J. 1987. Homologous domains in Trichoderma reesei cellulolytic enzymes: Gene sequence and expression of cellobiohydrolase II. Gene 51:43-52.

Tenberge, K. B. 1992. Ultrastructure and development of the outer epidermal wall of spruce (Picea abies) needles. Can. J. Bot. 70:14671487.

Tenberge, K. B., Homann, V., Oeser, B., and Tudzynski, P. 1996. Structure and expression of two polygalacturonase genes of Claviceps purpurea oriented in tandem: Cytological evidence for pectinolytic enzyme activity during infection of rye. Phytopathology 86:1084-1097.

Tenberge, K. B., and Tudzynski, P. 1994. Early infection of rye ovaries by Claviceps purpurea is inter- and intracellular. BioEng. Sonder- nummer 10(3):22.

Tenberge, K. B., and Tudzynski, P. 1995. Der Mutterkornpilz Claviceps purpurea auf Roggen: Affinitätscytochemische Untersuchungen einer Wirt-Parasit-Beziehung. Phytomedizin 25(3):51-52.

Tomme, P., van Tilbeurgh, H., Petterson, G., van Damme, J., Vandekerckhove, J., Knowles, J., Teeri, T., and Claeyssens, M. 1988. Studies of the cellulolytic system of Trichoderma reesei QM 9414. Eur. J. Biochem. 170:575-581.

Tudzynski, P., Tenberge, K. B., and Oeser, B. 1995. Claviceps purpurea Pages 161-187 in: Pathogenesis and Host Specificity in Plant Diseases: Histopathological, Biochemical, Genetic and Molecular Bases, Vol. II Eukaryotes. K. Kohmoto, U. S. Singh, and R. P. Singh, eds. Elsevier Science, Pergamon Press, Oxford.

Van den Ackerveken, G. F. J. M., Dunn, R. M., Cozijnsen, A. J., Vossen, J. P. M. J., van den Broek, H. W. J., and de Wit, P. J. G. M. 1994. Nitrogen limitation induces expression of the avirulence gene avr 9 in the tomato pathogen Cladosporium fulvum. Mol. Gen. Genet. 243:277-285.

Wang, P., and Nuss, D. L. 1995. Induction of a Cryphonectria parasitica cellobiohydrolase I gene is suppressed by hypovirus infection and regulated by a GTP-binding-protein-linked signaling pathway involved in fungal pathogenesis. Proc. Natl. Acad. Sci. USA 92:1152911533.

Wey, T. T., Hseu, T. H., and Huang, L. 1994. Molecular cloning and sequence analysis of the cellobiohydrolase I gene from Trichoderma koningii G-39. Curr. Microbiol. 28:31-39.

Wood, W. B. 1966. Host specificity of DNA produced by Escherichia coli: Bacterial mutations affecting the restriction and modification of DNA. J. Mol. Biol. 16:118-133. 